\title{
NEWS AND COMMENTS
}

\section{Scope of the Spanish Marine Sciences National Programme from 1995 to 2003}

\author{
BEATRIZ MORALES-NIN ${ }^{1,2}$ and PILAR SÁNCHEZ-FERNÁNDEZ ${ }^{1,3}$ \\ ${ }^{1}$ Dirección General de Investigación, Ministerio de Educación y Ciencia, Paseo de la Castellana 160, Madrid 28071, \\ Spain. E-mail:beatriz.morales@uib.es \\ ${ }^{2}$ CSIC/UIB-IMEDEA, Miquel Marqués 21, 07190 Esporles, Balears, Spain. \\ ${ }^{3}$ CEDEX, Alfonso XII 3 y 5, 28014 Madrid, Spain.
}

\section{INTRODUCTION}

The Spanish research has been funded since April 2004 by the new Ministry of Education and Science (Ministerio de Educación y Ciencia, MEC). From 2000 to 2004 it was funded by the Ministry of Science and Technology (Ministerio de Ciencia y Tecnología, MCyT), and before that it was funded by the Interministerial Commission of Science and Technology (Comisión Interministerial de Ciencia y Tecnología, CICYT), through the National Plans of Research, Development and Technological Innovation (Planes Nacionales de Investigación, Desarrollo e Innovación, PN I+D+I). These plans have a duration of four years with annual public, competitive invitations to tender which are peer-reviewed. The design of the knowledge areas and the programmes addressing them is carried out by the Ministry on the basis of the national priorities and the current topics addressed in the European Union Science and Technology Framework Programmes. The aim is to stimulate Spanish research and technological development in order to increase the competitiveness of Spanish science and its application to meet the demands of society and improve economic development. The main constituents of the Programmes were: i) Human Resources, including researcher mobility, graduate and post-graduate grants, and training of technicians; ii) Invitations to tender for Infrastructure, considered as medium- and large-scale facilities; iii) Innovation Projects involving cooperation with industry; iv) Research and Development (R\&D) Projects and Special Actions. Since 2000 the Programmes have been jointly funded by the European Regional Development Funds/European Social Funds.
Marine Sciences previously formed part of the Natural Resources science and technology area, and first had a specific programme in 1995. By 2003 it had therefore completed two full periods. It is therefore possible to make a comparative study of the evolution of the research area, which will provide useful information for the research community in Spain and elsewhere.

The present review includes the Research and Development Projects and Special Actions that were funded in the annual invitations to tender of the Marine Sciences and Technology programme (Programa de Ciencias y Tecnologías Marinas) 20002003, which are compared with the previous period. There are other programmes that funded related research, mainly the Antarctic (Programa Nacional Antártico) and Basic Science Knowledge (Promoción General del Conocimiento) Programmes, but these are not included herein. The data used are taken from the public domain (http://www.mcyt.es) and from data by the Sub-Directorate General of Research Projects (MEC).

\section{INVITATIONS TO TENDER AND EVALUATION PROCESS}

The Projects had annual invitations to tender with specific objectives (Table 1) within the general context of the R+D+I National Plan. The evaluation of the submitted proposals consisted of a two-step process: an administrative review in which compliance with the terms of the invitation to tender was checked, followed by a scientific peer review process lasting around six months. Two aspects 
TABLE 1. - The main objectives addressed in the Marine Sciences and Technologies programmes; these had a series of sub-objectives that changed annually. The number of approved projects and funds (Million $€$ ) per objective are also included. For comparative issues it is important to note that the first Programme had five invitations to tender while the second had only four.

\begin{tabular}{|c|c|c|}
\hline 1995-1999 & Number & Funds $(\mathrm{M} €)$ \\
\hline $\begin{array}{l}\text { Predicción Oceánica } \\
\text { Oceanography }\end{array}$ & 14 & 0.69 \\
\hline $\begin{array}{l}\text { Procesos biogeoquímicos y flujos de materia y energía } \\
\text { Biogeochemistry }\end{array}$ & 32 & 2.10 \\
\hline $\begin{array}{l}\text { Estudios litosféricos y registro sedimentario en márgenes continentales } \\
\text { Marine Geology }\end{array}$ & 7 & 0.60 \\
\hline $\begin{array}{l}\text { Investigación en la franja costera } \\
\text { Coastal Zone }\end{array}$ & 31 & 1.56 \\
\hline $\begin{array}{l}\text { Recursos vivos } \\
\text { Living Resources }\end{array}$ & 29 & 1.15 \\
\hline $\begin{array}{l}\text { Acuicultura marina } \\
\text { Aquaculture }\end{array}$ & 63 & 2.26 \\
\hline $\begin{array}{l}\text { Desarrollos tecnológicos } \\
\text { New Technologies }\end{array}$ & 13 & 0.47 \\
\hline $2000-2003$ & Number & Funds $(\mathrm{M} €)$ \\
\hline $\begin{array}{l}\text { Investigación oceanográfica en el contexto del cambio global } \\
\text { Global change }\end{array}$ & 22 & 1.92 \\
\hline $\begin{array}{l}\text { Funcionamiento de los ecosistemas marinos } \\
\text { Ecosystems }\end{array}$ & 38 & 3.05 \\
\hline $\begin{array}{l}\text { Actividad pesquera sostenible } \\
\text { Sustainable Fisheries }\end{array}$ & 25 & 1.66 \\
\hline $\begin{array}{l}\text { Desarrollo de estudios integrados de la franja costera y plataforma continental } \\
\text { Coastal Zone }\end{array}$ & 49 & 3.34 \\
\hline $\begin{array}{l}\text { Investigación de riesgos relacionados con los recursos marinos } \\
\text { Pollution }\end{array}$ & 28 & 1.76 \\
\hline $\begin{array}{l}\text { Desarrollo de tecnologías nuevas y competitivas } \\
\text { New Technologies }\end{array}$ & 13 & 0.68 \\
\hline
\end{tabular}

were considered in the evaluation: i) the scientific aspects evaluated by the National Agency for Evaluation and Future Studies (Agencia Nacional de Evaluación y Prospectiva, ANEP); and ii) the relevance and adaptation to the invitation to tender, budget aspects and team composition, evaluated by a panel of experts proposed by the programme manager (Table 2). The evaluators were selected for their excellence and expertise with regard to the objectives of the invitation to tender, and were not directly involved in the invitation. Also, care was taken to not repeat the evaluators from year to year and to source them from different geographical areas (Table 2) and different parent institutions (Universities, the Scientific Research Council of Spain (Consejo Superior de Investigaciones Científicas, CSIC), and the Spanish Institute of Oceanography (Instituto Español de Oceanografía, IEO)) (Table 2). Finally,
TABle 2. - Composition of the Ministry's expert panel by area (autonomous regions) and their parent organisation.

\begin{tabular}{lrlr}
\hline Area & $\%$ & Organisation & $\%$ \\
\hline Valencian Community & 3 & Universities & 50 \\
Asturias & 3 & IEO & 13 \\
Andalusia & 24 & Others & 3 \\
Balearic Islands & 11 & CSIC & 34 \\
Catalonia & 16 & & \\
Galicia & 21 & & \\
Madrid & 8 & & \\
Canary Islands & 11 & & \\
Cantabria & 5 & & \\
\hline
\end{tabular}

the evaluations were discussed in a panel with the participation of the evaluators and Ministry representatives. From this, a priority list was drawn up and a budget was approved for each proposal passing the selection threshold. The pre-selected projects were finally approved depending on the available 
Table 3. - Summary of the two Marine Science Programmes.

\begin{tabular}{|c|c|c|}
\hline Programme & 1995-1999 & $2000-2003$ \\
\hline Special Actions & $\begin{array}{l}95 \text { Approved } \\
€ 1.86 \text { million }\end{array}$ & $\begin{array}{l}119 \text { Approved } \\
€ 2.59 \text { million }\end{array}$ \\
\hline R\&D Projects & $\begin{array}{l}402 \text { Proposals } \\
189 \text { Approved }(47 \%) \\
€ 9.14 \text { million }\end{array}$ & $\begin{array}{l}341 \text { Proposals } \\
175 \text { Approved }(51 \%) \\
€ 12.41 \text { million }\end{array}$ \\
\hline Fellowships & 45 Predoctoral & 49 Predoctoral \\
\hline Researchers & $\begin{array}{l}112 \text { person year-1 } \\
\text { Total: } 550 \text { person year }^{-1}\end{array}$ & $\begin{array}{l}195 \text { person year }^{-1} \\
\text { Total: } 780 \text { person year }^{-1}\end{array}$ \\
\hline
\end{tabular}

budget and after the acceptance of the terms of approval by the project leader. Additionally, when a research vessel was needed, the acceptance of the proposal depended on ship time availability.

Once the conformity of the proposal with the objectives of the invitation to tender-and hence to the national research priorities-had been determined, the main approval criteria were the scientific relevance of the proposal and the feasibility of the objectives with the scientific and technical team. Additionally, the adaptation of the material and methods to the objectives was also evaluated. The budget aspects were less relevant because if necessary a new budget was suggested by the experts.

The projects generally had a duration of three years, with annual budgets and annual reports. The ongoing projects were reviewed annually in a continuous evaluation process conditioning the payment of the annual budget. The final payment was at the beginning of the third year and was subject to the approval of the second annual report.

The Special Actions were mainly for the payment of the funding of the infrastructure not covered by the European Union (EU) Projects and for some special activities such as organising symposia, invitations to participate in international research cruises, meetings for drawing up international proposals and establishment of networks. The Special Actions were more flexible and continuously open, and had a simpler evaluation process.

\section{APPROVED ACTIONS}

A total of 294 projects and Special Actions were funded in the 2000-2003 period (Table 3), corresponding mainly to R\&D Projects (175), followed by Special Actions (86) and co-funding of EU Pro- jects (33). Of the total budget of $€ 14.99 \mathrm{M}$, the amounts assigned to these were $€ 12.41 \mathrm{M}, € 1.92 \mathrm{M}$ and $€ 0.66 \mathrm{M}$ respectively. The evolution over the four-year period showed a marked increase in the number of actions approved (Fig.1a), which is paralleled by the funding (Fig. 1b).

\section{THE RESEARCHERS}

The majority of the projects have inter-institutional teams, and it is even quite common for international organisations to be partners. However, as it is very complicated to analyse the partnership, the results here refer to the scientific coordinator institution. The task force involved in the projects annually was 195 person year ${ }^{-1}$ (EDP), corresponding to a total of 780 EDP. There was also a great demand for funding to contract additional personnel, and a
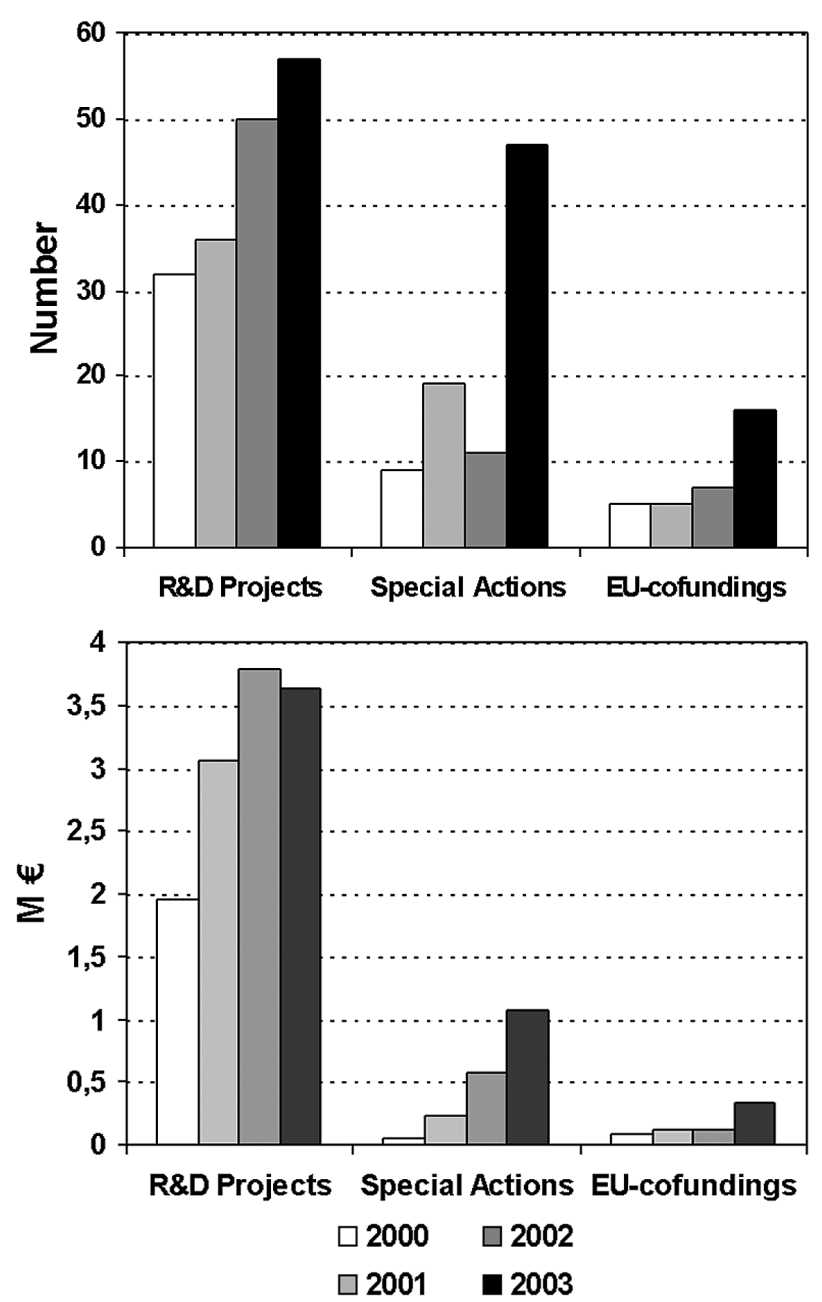

FIG. 1. - Annual distribution of the approved Projects and Special Actions in the second Programme by: a) number and b) funding in million $€$. 

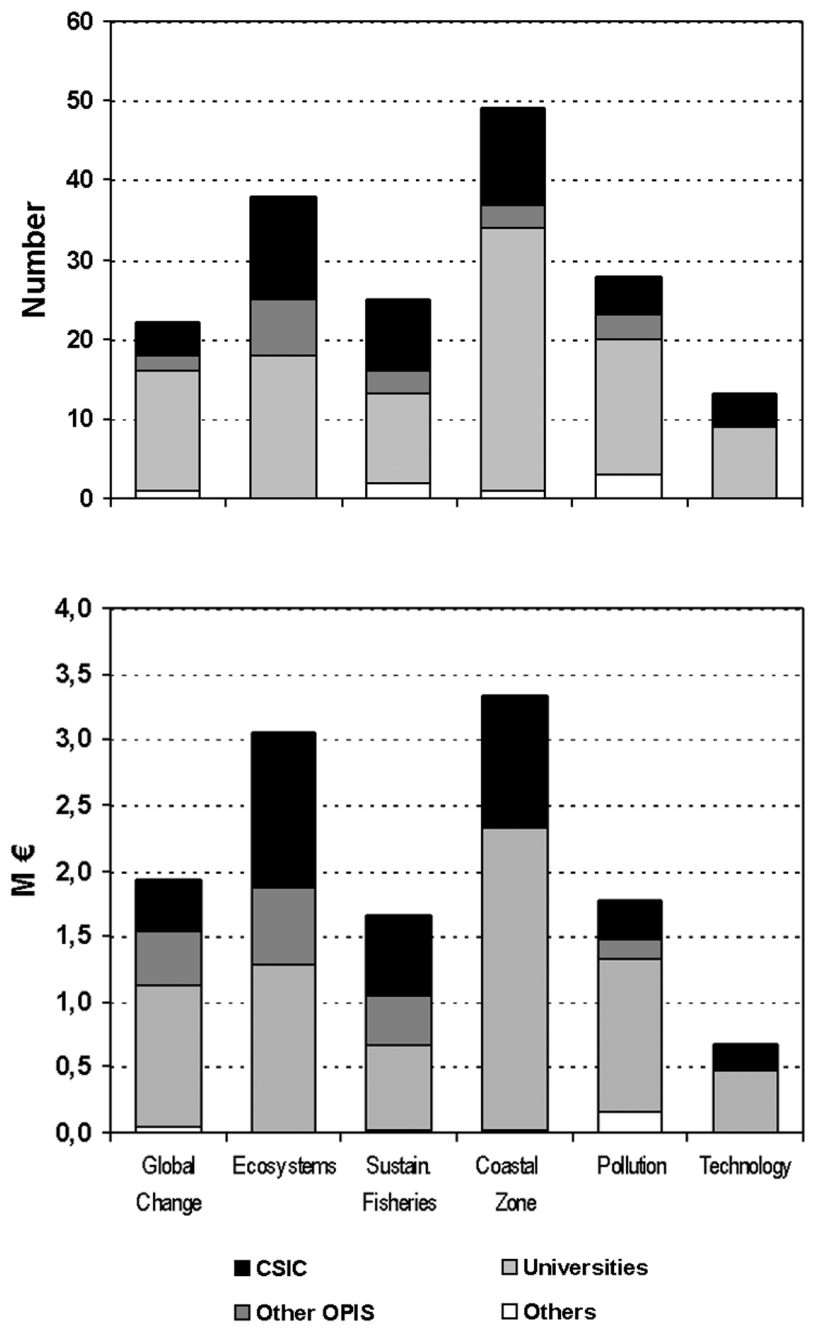

FIG. 2. - Distribution of the participation of the main research bodies by objectives during the Second Programme (2000-2003 period) by: a) project numbers and b) budget. CSIC: Science Council of Spain, OPIS: Public Research Organisations.

total of 45 contracts for scientists and technicians were included in the budgets, corresponding $42 \%$ of the total to 2003. Associated with the projects, a total of 49 pre-doctoral fellowships were also granted for the full period.

Marine research is mainly carried out by universities which were awarded $58.9 \%$ of the $R \& D$ Projects (56\% of the total funding), followed by the CSIC ( $25 \%$ of the projects and $29.7 \%$ of the budget), and other public research bodies (10.3\% of the projects and $12.3 \%$ of the budget), mainly the IEO.

When we consider the involvement of the different research bodies by scientific objectives (Fig. 2), it is clear that the coastal zone and the ecosystemic aspects were the most relevant objectives in the number of projects, while technological development was the objective with least projects.
The regional participation shows that Catalonia is leading, followed by Galicia and Andalusia (Table 3 ). The predominance of these is naturally related to their importance in population and in coastline, but also depends on the presence in these regions of many universities and the IEO and CSIC. However, the revenue of the projects (funds per project) shows that the Valencian Community, the Balearic Islands and the Basque Country are obtaining better relative results.

\section{EVOLUTION FROM THE FIRST TO THE SECOND PROGRAMME PERIOD}

Although the two Programmes had an official duration of four years, the first one had a special invitation to tender at the beginning, thus comprising five invitations for R\&D Projects (1995-1999). Also, the first Programme was co-funded by the IEO using funds from the Fisheries Directorate.

Some changes were made in the Programme objectives from the first to the second Programme (Table 1). The main one was the transfer of aquaculture issues to another Programme. Marine geology was included partly in the coastal zone objectives, with the other aspects transferred to the Earth Sciences Programme. The change from objective living resources to sustainable fisheries reflects the change of paradigm in the fisheries field to a more ecosystemic approach. Also, oceanography and biogeochemistry were readdressed as global change. Pollution aspects were incorporated in the second Programme. Regarding participation by objectives, the coastal zone was the most sought after in both periods. The technological aspects showed only a slight increase in participation during the eight-year period, showing that either the scientific community was using other funding programmes involving enterprise participation (like PETRI), or there is a lack of development in this important aspect.

It is interesting to point out the increase in the participation of the scientific community in projects from 110 persons year ${ }^{-1}$ in $1995-1999$ to 195 person year ${ }^{-1}$ in 2000-2003, representing a total of 550 and 780 person year-1 ${ }^{-1}$ respectively for the full Programmes (Table 3 ). The mean dedication per project was 3.4 person year ${ }^{-1}$ in 1995-1999 and 4.1 person year $^{-1}$ in $2000-2003$. This increased participation is linked to the inclusion in the evaluation criteria of the size of the research team and other requirements leading to the formation of larger teams, such as the limit in number of proposals participation. Besides, 
pre and post-graduate students were allowed to form part of the teams only after 1999, resulting in the participation of 1-2 students in each project. The funding also increased over the period (Table 3), following the general tendency of increasing funding in R\&D. The percentage of funds awarded to funds requested was $28.1 \%$ in $1995-1999$ (for $47 \%$ of the approved projects) and $27.7 \%$ (for $51 \%$ of the approved projects) in 2000-2003. Considering only the approved projects, this percentage was $58.1 \%$ in 1995-1999 and 51.9\% in 2000-2003.

\section{DISCUSSION}

Although the results presented herein are indicative of the R\&D in marine sciences in Spain, in fact the amount of activity is greater due to the existence of a specific Aquaculture programme as well as programmes in Antarctic research, which is mainly marine, and in basic knowledge, which includes some aspects of biodiversity, biology and evolution of marine organisms. Moreover, the IEO receives direct funding from the Fisheries Secretary (Ministry of Agriculture and Fisheries) for applied research.

The consolidation of universities as the main actors in marine sciences has confirmed the tendency detected in the first years of the programmes (Duarte and Tintoré, 1996). Also, the importance of Catalonia, Galicia and Andalusia in marine research has been maintained. This is probably due to the size of their scientific community, because the success rates show that other communities, although smaller, have teams that are able to obtain a good ratio between tenders and funded projects.

The human resources involved in the R\&D projects have almost doubled since the first National Plan and now involve a relevant part of the marine science community. The projects tend to be more interdisciplinary and more complex, and involve more human resources. In addition to this increasing involvement, there has been a great demand for funds for support staff, reflecting one of the great problems of science in Spain: a serious shortage of technicians and laboratory staff, particularly at universities.

The analysis of the tendency of the funding over the eight years studied corresponding to two National Plans shows a $36 \%$ increase in funding, an a higher success rate (51 to $47 \%$ ) and a higher mean budget per project ( $€ 70.900$ to $€ 48.300$ ), although the
TABLE 4. - Distribution of the approved projects and funds by regions.

\begin{tabular}{lrr}
\hline & \% Projects & \% Funds \\
\hline Andalusia & 23.7 & 19.9 \\
Aragon & 0 & 0 \\
Asturias & 4.2 & 4.4 \\
Balearic Islands & 5.9 & 9.1 \\
Canary Islands & 6.8 & 6.6 \\
Cantabria & 3.4 & 2.9 \\
Castile-La Mancha & 0.8 & 0.2 \\
Catalonia & 27.1 & 30.8 \\
Galicia & 20.3 & 16.7 \\
Madrid & 4.2 & 4.5 \\
Murcia & 0 & 0 \\
Navarre & 0 & 0 \\
Basque Country & 2.5 & 3.5 \\
Valencian Community & 0.8 & 1.4 \\
& & \\
\hline
\end{tabular}

rate of fund requested to funds approved has not changed significantly (27.7 to $28.1 \%$ ). If we consider these results related to the totality of the National R+D+I Plans for 2000-2003 with 21 Programmes, the sub-programme of Marine Sciences represents only $1.74 \%$ of the budget (€864 M) with similar rates of proposals $(1.72 \%)$ and approved projects $(1.62 \%)$ to other programmes. Considering the success rate, which is $54.6 \%$ on average for the totality, marine sciences are competitive although the mean project budget is lower, at an average of $€ 80.000$.

The difference between the budgets requested and awarded means that the marine science community must obtain additional resources from all available sources. The co-funding of Spanish research is necessary because overall less than $40 \%$ of the approved projects obtain $75 \%$ of the requested budget, so the scientific community must obtain funds from regional research projects (37\%), the EU (22\%) or industry (17\%) (MCyT figures).

The R\&D investment of the Ministry reached $1.03 \%$ of GDP in 2003. There are no actual figures on investment in marine sciences, but it was considered to be less than $0.5 \%$ of GDP despite the fact that marine-related issues generate 10\% of GDP (Delgado et al. 1999). At present the proportion devoted to marine sciences has probably not changed significantly, although due to the "Prestige" wreckage and oil-spill a Strategic Action has been designed and more than $€ 10 \mathrm{M}$ will be devoted to related research. Indirectly, the investment in marine sciences has increased with the planned construction of a new research vessel, the running and renovating of the " $\mathrm{R} / \mathrm{V}$ Hespérides" and the increase in technical support through a new technological unit to be added to the existing one. Also, a new coordinating unit for 
the management of research vessels was created in 2003, allowing a better use of the expensive infrastructures required for marine science research. The new National Plan for 2004-2007 has the goal of increasing investment and stimulating the participation of enterprises and industry. The amount of funding is to be increased considerably to $1.22 \%$ of GDP (Gross Domestic Product) by 2005. Considering that in 2001 the investment was $0.44 \%$ of GDP, this is a significant increase. In the context of the European Union, the mean inversion was $0.67 \%$ in 2001 and should increase accordingly, so the gap between Spain and its neighbours will probably decrease. However, the amount devoted to marine sciences in the context of a competitive National Plan would depend on the capacity of marine researchers to submit top-quality proposals that would force more funds to be devoted to this area of knowledge. Moreover, the increasing public awareness of the importance of marine-related issues (transport, tourism, production, recreational uses of the coastline, urbanism, etc.) would also influence the budget assigned to marine sciences, and this awareness depends mainly on the scientific community.

\section{ACKNOWLEDGEMENTS}

We thank Dr. Guillermo Morales (MEC) and Dr. Enrique Tortosa (IMEDEA) for their helpful comments resulting in an improved document.

\section{REFERENCES}

Duarte, C.M. and J. Tintoré. - 1996. La investigación en Ciencias Marinas en España. Política Científica, 46: 11-20.

Delgado, M.J., C.M. Duarte, J. Tintoré and G. Parrilla. - 1999. Las ciencias marinas en España a final de siglo. El pulso de la investigación en ciencias marinas en España. Dirección General de Investigación y Desarrollo, Madrid: 71-75.
SUMMARY: Marine Research in Spain was funded mainly by the National Plans of the Ministry of Science and Technology. These have four-year duration and comprise priority research areas addressed by Research and Development Programmes. Marine Sciences has been identified as a Programme since 1995, and forms part of two National Plans. The Programme made annual invitations to tender with the following objectives: global change, ecosystems, sustainable fisheries, coastal zone, pollution and new technologies. Each objective had several sub-objectives. In the first period (1995-1999) Aquaculture was one of the objectives, and it had its own Programme in the second. The 1995-1999 Programme approved 189 projects (47\% of the proposals submitted) with a budget of $9.14 \mathrm{M} €$ and a participation of 550 persons/year. In the 2000-2003 Programme 175 projects were approved $(51 \%$ of the proposals submitted) corresponding to $€ 12.42 \mathrm{M}$ and 780 persons/year. The universities were the principal actors $(58 \%$ of the projects), followed by the Science Council (25\% of the projects). Catalonia is the region with the greatest participation both in projects and in funding, followed by Galicia and Andalusia. Considering that in the first period there were five invitations to tender and Aquaculture was the main objective ( 63 projects and $€ 2.26 \mathrm{M}$ ), the increase in participation and funding is considerable. This trend is also confirmed by the increase in success rate (approval of proposals rose from $47 \%$ in the first invitation to tender to $51 \%$ in the second) and the increase in the mean budget per project (from $€ 48.300$ to $€ 70.900$ respectively).

RESUMEN: Evolución del Programa NaCional de Ciencias MARINAS EN ESPAÑA DE 1995 A 2003. - La investigación marina en España estaba financiada principalmente por el Plan Nacional del Ministerio de Ciencia y Tecnología. Estos Planes tienen duración cuatrianual, están compuestos por áreas prioritarias con sus respectivos Programas. Dentro de los dos Planes realizados entre 1995 y 2003, ha existido un Programa de Ciencias Marinas. El Programa ha convocado anualmente solicitudes de proyectos para los objetivos científicos siguientes: cambio global, ecosistemas, pesquerías sostenibles, zona costera, contaminación y nuevas tecnologías, que a su vez constaban de varios subobjetivos específicos. En el primer Programa la Acuicultura formaba parte de los objetivos, pasando a su propio Programa posteriormente. En el período 1995-1999 se financiaron 189 proyectos (47\% de los solicitados) con un presupuesto de $9,14 \mathrm{M} €$ implicando un total de 550 personas/año con dedicación plena. En el periodo 2000-2003 fueron 175 proyectos (51\% de los solicitados), correspondiendo a 12,42 M€ y 780 personas/año. Las Universidades son los principales actores en el ámbito de la Ciencia Marina (58\% de los proyectos) seguidas por el Consejo Superior de Investigaciones Científicas (CSIC) (25\% de los proyectos). Por otra parte, Cataluña es la Comunidad Autónoma con una mayor participación, seguida por Galicia y Andalucía. Considerando que en el primer período hubo 5 convocatorias y que la Acuacultura fue el principal objetivo (con 63 proyectos y $2.26 \mathrm{M} €$ ), se ha experimentado un crecimiento relevante en participación y financiamiento. Esta tendencia se confirma por el mayor índice de éxito (47\% y $51 \%$, de los proyectos solicitados aprobados) y con un promedio de financiación por proyecto superior $(48.300 €$ contra $70.900 €)$. 